\title{
A New RNA Synthesis of Cells: A Possible End of Birth Defects
}

\author{
Aaron Wallman* \\ California State University, 401 Golden Shore, Long Beach, 90510, USA \\ *Corresponding author: Aaron Wallman California State University, 401 Golden Shore, Long Beach, 90510, USA, Tel: 310-502-5889; E-mail: \\ aaron.wallman@yahoo.com
}

Received date: February 07, 2017; Accepted date: February 21, 2017; Published date: February 28, 2017

Copyright: ( 2017 Wallman A. This is an open-access article distributed under the terms of the Creative Commons Attribution License, which permits unrestricted use, distribution, and reproduction in any medium, provided the original author and source are credited.

Citation: Wallman A (2017) A New RNA Synthesis of Cells: A Possible End of Birth Defects. Mol Biol 6: 187. doi:10.4172/2168-9547.1000187

\section{Commentary}

According to Dr. Klaasmeir, each species has a specific ratio of nitrogen/phosphorous. In the case of plankton, for example, the nitrogen/phosphorous ratio would be $\mathrm{N}: \mathrm{P}=16$ and in deep oceanic water the ratio would be $\mathrm{N}: \mathrm{P}=15$ [1]. Dr. Karpinets believes nitrogen and phosphorous as this ratio dominate unicellular organisms. In addition, "the basic functions of initiation, elongation and termination in the ribosome of bacteria resemble those of eukaryotes" [2]. Under adverse conditions, Dr. Karpinets thinks that the act of each gene's encoding of cellular maintenance decreases as well.

With a birth defect like Downs Syndrome, Dr. Menkes contends that there are abnormalities in the chemical composition and the structure of such a person's brain which I as well as some professors believe are from a faulty synthesis of RNA [3].

Dr. Konrad claims that, "the lack of a comparable reduction in protein synthesis during mitosis should be interpreted as evidence for the presence in these cells of a relatively stable messenger RNA [4]." Later in this article, I will mention those professors whom I believe link an unstable RNA messenger to birth defects.

Like Dr. Schultz's discovery of the chemical compound reversine's positive effect on the metaphase during mitosis, I believe that the influence of a chemical compound with a ratio as nitrogen/ phosphorous renews a cell's abnormal instructions with normal ones as the two daughter cells separate on the metaphase plate during their mitosis [5]. To Dr. Maayan, the mitosis of cells reflect such a replication of this genetic material as they replicate as either an abnormal or normal trait of a person [6].

In more precise terms, Dr. Watts concludes that a person's abnormal trait like congenital blindness can be traced to a faulty synthesis which to me leads to an unstable RNA messenger [7]. In even more specific terms, Dr. Haldeman-Englert observes that the origin of such a birth defect is from an extra chromosome or another type of error during their past meiosis which I believe is misdirected by its protein synthesis. Furthermore, I believe that its misdirection can be traced to an unstable RNA messenger [8].

In his article, "Cells Keep a Memory of their Tissue Origin During Axolotl Limb Regeneration," Dr. Kragl thinks that cells keep a memory of their tissue origin during limb regeneration of an axolotl such as a
Mexican lizard for example [9]. With such correct and matching input, which is traced to a faulty past meiosis of a person, I propose that in their laboratories, researchers should measure the ratio of nitrogen and phosphorous for a person's new RNA synthesis which leads to a stable RNA messenger during the mitosis of his or her birth defect. Moreover, such an occurrence results in this birth defect's end with the correct amino acid sequences.

Based on the data of this article, such elements of nitrogen and phosphorous along with protein underline the growth rate of either the birth defect or normal trait of an organism. In my opinion, an estimation of these two above elements as a chemical compound leads a human's birth defect to have the correct amino acid sequence as previously mentioned and then become a normal trait. With the correct calculation of the compound of nitrogen and phosphorous for an unstable RNA messenger, which is traced to a birth defect, a researcher can discover the ideal growth rate for its stability as an RNA messenger and then its end as a birth defect. On this basis, I invite students and researchers to consider this point of mine with the data of this article.

\section{References}

1. Klassmeier C (2003) Optimal nitrogen-to-phosphorous stoichiometry of phytoplankton. Nature 429: 171-174.

2. Karpinets VT (2006) RNA: Protein ratio of the unicellular organism as a characteristic of phosphorous and nitrogen stoichiometry and of the cellular requirement of ribosomes for protein synthesis. BMC Biol.

3. Menkes JH (1967) The pathogenesis of mental retardation in phenylketonuria and other inborn errors of amino acid metabolism. Pediatrics 39: 297-308.

4. Konrad CG (1963) Protein synthesis and RNA synthesis during mitosis in animal cells. J Cell Biol 19: 267-277.

5. Peter GS (2007) Reversine increases the plasticity of lineage-committed mammalian cells. Proc Natl Acad Sci USA 104: 10482-10487.

6. Inbar M (2011) Meiosis in human. The Embryo Project Encyclopedia.

7. Watts RWE (1962) Congenital abnormalities of amino-acid metabolism. Dev Med Child Neurol 4: 405-417.

8. Haldeman-Englert CMD. Medical genetics: How chromosome abnormalities happen. University of Rochester Medical Center Health Encyclopedia.

9. Kragl M (2009) Cells keep a memory of their tissue origin during axolotl limb regeneration. Nature 460: 60-65. 